\title{
Kompozit Kolon-Betonarme Kiriş Birleşim Noktasının Tersinir Tekrarlı Yükler Altındaki Davranışının Numerik Olarak İncelenmesi
}

\author{
Bengi ARISOY ${ }^{*}$, Fethi ŞERMET ${ }^{2}$ \\ ${ }^{1}$ Ege Üniversitesi, Mühendislik Fakültesi, İnşaat Mühendisliği Bölümü, 35050, İzmir \\ (ORCID: 0000-0002-2785-0609)
}

${ }^{2}$ Ege Üniversitesi, Mühendislik Fakültesi, İnşaat Mühendisliği Bölümü, 35050, İzmir (ORCID: 0000-0001-8221-689X)

(Alınış / Received: 21.04.2017, Kabul / Accepted: 01.11.2017, Online Yayınlanma / Published Online: 20.01.2018)

Anahtar Kelimeler Özet: $\mathrm{Bu}$ çalışmada beton içine gömülü çelik profil ile Betonarme düğüm noktası, Kompozit kolon, Sonlu elemanlar modeli oluşturulmuş kompozit kolon ve betonarme kiriş birleşim bölgesinin tersinir tekrarlı yükler etkisi altındaki davranışı nümerik olarak incelenmiștir. Çalışma kapsamında dügüm noktasının süneklik mertebesi ve göçme şekli incelenmiş, betonarme kolon-kiriş birleşim bölgesi performansı ile karşılaştırılmıştır. Kompozit kolon içinde yer alan çelik profil çekirdek deformasyonların çoğunu sönümlemektedir. Artan yükler etkisi altında, çelik profil etrafında yer alan betonun ezilip, yumuşak donatının akmasına rağmen, çelik profil çekirdek akma mertebesine erișmemektedir. Bununla beraber kolonda oluşan lokal hasarların (betonda ezilme/yumuşak donatıda akma) düğüm noktasının davranıșına etkisi önemlidir. Kuvvetli kolonzayıf kiriș tasarımı gözetilmiș olan çerçeve iç birleșim bölgesi, sonlu elemanlar ile modellenmiş ve ABAQUS programı ile analiz edilmiştir. Betonarme kolon-kiriş ve kompozit kolon-betonarme kiriş ile teşkil edilmiş düğüm noktaları tekrarlı tersinir yük etkisi altındaki analiz edilmiş ve analiz sonuçları her iki birleşim bölgesinin göçme mekanizmaları, süneklik mertebeleri ve dayanımları açısında değerlendirilmiştir. Analiz sonuçları her iki birleşim şeklinde de kolon ve kiriş birleşim yüzeylerindeki betonun ezilmesine rağmen, kompozit kolon-betonarme kiriş birleșimi betonarme kolon-kiriș birleşimine göre göçmeden önce 1,32 kat daha fazla yük taşımış, 1,56 kat daha fazla yer değiştirme yapmıştır. Betonarme kolon-kiriş birleşim bölgesinde dayanım betonun ezilmesi ile kontrol edilirken, kompozit kolon-betonarme kiriş dügüm noktasında çelik profilin akması ile kontrol edilmiştir. 


\section{Numerical Analysis of Behavior of The Composite Column-Reinforced Concrete Beam Joints Subjected to Cyclic Loads}

\begin{tabular}{l}
\hline Keywords \\
Reinforced \\
concrete joints, \\
Composite \\
columns, \\
Finite element \\
modeling
\end{tabular}

*Sorumlu yazar: bengi.arisoy@ege.edu.tr

\section{Giris}

Sismik yükler etkisi altındaki çerçeve sistemlerde, kolon-kiriș birleșim bölgesi en kritik bölge olduğu gibi davranışı en az anlaşılan bölgedir. Birden fazla elemanın birleștiği düğüm noktaları, eğilme, kesme ve eksenel yük kombinasyonları altında karmaşık bir davranış sergiler. Bu karmaşık davranış, düğüm noktalarında birleșen elemanların farklı özelliklere sahip olması, kompozit eleman ile betonarme elemanın oluşturduğu birleșim bölgesi gibi, ile daha da artmaktadır. Kompozit elemanların yük etkisi altındaki davranıșlarının belirlenmesine ait çalışmalar 1940'lı yıllarda başlamasına rağmen, birleşim bölgelerine ait çalışmalar daha yenidir. Konu üzerine yapılmış çalışmalar aşağıda özetlenmiştir.
Lee ve çalışma arkadaşları kompozit döșeme-çelik kolon elemanlardan inșa edilmiş altı katlı prototip çerçeve sistemi tersinir tekrarlı yükler etkisi altında test etmişler, kompozit döşemenin çelik kolona bağlandığı birleşim bölgesinin dönme rijitliğini arttırdığını rapor etmişlerdir [1-3]. Chung-Che ve ChiaMing (2002), normal beton kullanarak moment aktaran betona gömülü kompozit kolon-çelik kiriş birleşim noktasının tersinir tekrarlı yükleme altındaki performansını incelemișlerdir ve tersinir yük etkisinde mafsallaşmaların çelik kirişlerde oluștuğunu ancak kompozit kolonun kirişin saplandığı beton yüzeylerinde göçmelerin gerçekleştiğini rapor etmişlerdir [4]. Mu-Xuan ve çalışma arkadaşları (2013), normal dayanımlı beton kullanılarak kompozit kolon-çelik kafes kiriş hibrit birleşim noktasının 
B.Arısoy ve F. Şermet / Kompozit Kolon-Betonarme Kiriș Birleşim Noktasının Tersinir Tekrarlı Yükler Altındaki Davranıșının Numerik Olarak İncelenmesi.

sismik davranışını incelemişlerdir. Çalışma kapsamında kompozit elemanların yük-deplasman eğrileri, birleşim noktasında kesme kuvveti davranışı, dayanım, rijitlik, süneklik, enerji yutma kapasitesi ve deformasyon analiz edilmiștir [5]. Fei-Yu Liao ve çalışma arkadaşları, beton ile doldurulmuş çelik tüp kompozit tekrarlı yükler altında davranışını deneysel olarak incelemişlerdir. Kompozit kolonların dayanıklılık, süneklik, rijit deformasyon ve enerji yutma kapasitesi incelenmiştir [6]. Lei Zeng ve çalışma arkadaşları, yüksek dayanımlı betondan üretilmiş kompozit çerçeve sisteminin tekrarlı yükleme altındaki davranıșını incelemişlerdir. Tüm deney elemanları birleşim noktasının kesme açısından yetersiz davranış sergiledikleri bildirmişlerdir [7]. Cristina ve çalışma arkadaşları, yüksek dayanımlı beton kullanarak betona gömülü çelik kompozit kolonların monotonik ve tekrarlı yükler altındaki davranışını incelemişlerdir [8]. Cheng-Cheng Chen ve çalışma arkadaşları, betona gömülü geniş flanşlı yapısal çelik profilin tekrarlı yükler altındaki davranışını incelemişlerdir. Çalışmada eğilme eksenine bağlı olarak çelik profilin ana eksen ve zayıf ekseninin süneklik ve sargılama üzerine etkisi incelenmiştir [9].

İncelenmiş çalışmalarda genel olarak kompozit kolon, kompozit kolonkompozit kiriş birleşimi, kompozit kolonçelik kiriş birleşimi davranışı incelenmiştir. $\mathrm{Bu}$ çalışmada betona gömülü çelik profil ile imal edilmiş kompozit kolon-betonarme kiriş birleşim bölgesinin tekrarlı tersinir yükler etkisi altındaki davranışı nümerik olarak incelenmiştir. Nümerik analiz sonuçları betonarme kolon-kiriş birleşimi için de tekrarlanmış ve sonuçlar kıyaslanmıştır.

\section{2. Çalışmanın Kapsamı}

Depreme dayanıklı çerçeve türü yapı tasarımında deprem yükünün şekil değiştirmeler ile harcanması temel alınmaktadır. $\mathrm{Bu}$ yaklaşımda en önemli parametre yapının sünekliğidir. Sünek bir yapı, elemanlarının deprem yükleri etkisi altında plastik şekil değiştirmeler yapmasına rağmen dayanımını korur. Betonarme yapılar sünek davranışın sağlanması için donatılandırılırlar. Özellikle kolon elemanlarda sünek davranışın garanti edilmesi amacıyla farklı tasarımlara da gidilmektedir. Çelik profil çekirdekli betonarme kolon bunlardan biridir. $\mathrm{Bu}$ çalışmada kolon elemanın sünekliğini arttırmak amacı ile I kesitli yapısal çelik elemanı betona gömülerek çelik çekirdekli bir kompozit kolon tasarlanmıştır. Dügüm noktasında yer alan kiriş eleman olarak ise uygulamada yaygın olarak kullanılan kompozit kiriş yerine betonarme kiriş tasarlanmıştır. Böylece kompozit kolonbetonarme düğüm noktası elde edilmiştir. Konu hakkında yapılmış çalışmalar kompozit kolonların sismik yükler etkisi altında sünek davranış gösterdiğini teyit etmiştir ([10-15], ve birçok diğer çalışmalarda). Bununla beraber, kompozit elemanlardan oluşan düğüm noktalarının davranışı düğüm noktasını oluşturan elemanların tipine göre farklılı göstermektedir. $\mathrm{Bu}$ çalışmada kompozit kolon-betonarme kiriş birleşim bölgesinin tersinir tekrarlı yükler etkisi altındaki davranışı nümerik olarak incelenmiştir. Çalışma aynı zamanda betonarme kolon-kiriş birleşim bölgesinin incelenmesini de kapsamaktadır. Böylece farklı iki şekilde tasarlanmış düğüm noktasının sismik yükler etkisindeki davranışı kıyaslanabilecektir.

\section{Kolon-kiriş birleşim bölgesi sismik davranışı}

Moment aktaran çerçevelerin süneklik ve deformasyon kapasitesi dügüm 
B.Arısoy ve F. Şermet / Kompozit Kolon-Betonarme Kiriș Birleşim Noktasının Tersinir Tekrarlı Yükler Altındaki Davranışının Numerik Olarak İncelenmesi.

noktalarının göçmeden sonra yük taşıma kapasitesine bağlıdır. Kolon-kiriş düğüm noktasının davranışı da yüklerin harcanmasında zayı olan kesme dayanımı ve donatı ve beton arasındaki aderans kuvvetleri ile kontrol edilir. Bir kolon-kiriş birleşiminde, kendisine bağlanan elemanlardan gelen kuvvetleri diğerlerine aktaracak dayanıma sahip olması, kolonların üzerlerine gelen yükü kolaylıkla taşıyabilmesi için düğüm noktasında oluşacak çatlakların sınırlı olması ve düğüm noktalarının deformasyonunun kat rölatif deformasyonunu arttırmaması beklenir [16]. Bunlara ek olarak da, moment aktaran çerçevelerde kuvvetli kolon-zayıf kiriș tasarım prensibine göre tasarımda, plastik mafsalların kirişlerin uçlarında oluşması ve kirişlerin tasarım gücü ötesinde eğilme direnci geliştirmesi beklenmektedir. Bununla beraber tasarım kurallarına uyulsa bile, düğüm noktasının sünekliği, düğüm noktasına bağlanan elemanların dayanımlarının birbirine uygun olması sağlanmalıdır.

Betonarme elemanlarda aderans kuvvetlerini arttıran unsurlar donatı yüzeyi, donatılar arasındaki beton miktarı, sürtünme yüzeyi miktarı, donatının beton ile çok iyi sarılmış olması olarak sıralanabilir. Belirtilen unsurlar kesme kuvvetlerinin aktarılması, dolayısı ile düğüm noktasının performansını etkilemektedir.

$\mathrm{Bu}$ çalıșmada, kolon elemanın içine yerleştirilecek çelik profil, önceki paragrafta belirtilen beton-donatı aderans kuvvetlerini etkileyecek unsurları sağladı̆̆ı gibi sürtünme yüzeyi açısından daha etkilidir ve dügüm noktasının performansını arttırması beklenmektedir.

\section{Eleman tasarımı}

Çalışma kapsamında nümerik analizi yapılacak olan birleşim bölgesi düzlem çerçeve ara düğüm noktasıdır (Şekil 1).

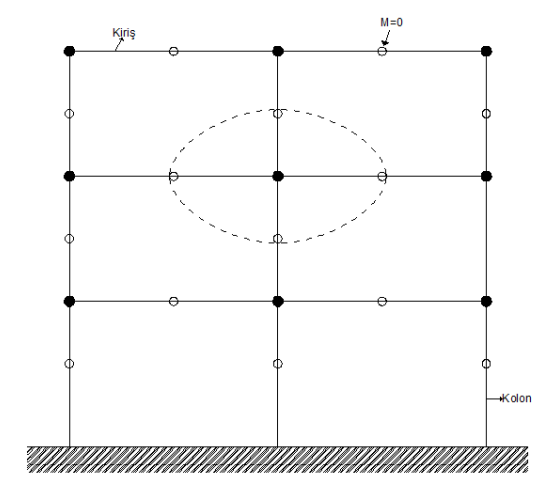

Şekil 1. Nümerik analizlerde modellemesi yapılacak olan düğüm noktası (kesikli oval şekil ile gösterilmiştir)

Dügüm noktasına saplanacak olan elemanların boyutları yatay yük etkisindeki çerçevenin moment sıfır noktalarından yararlanarak tespit edilmiştir. Nümerik analizlerde modellenecek olan düğüm noktasını teșkil eden betonarme kolon- kiriș elemanların tasarımları betonarme kolon/kiriş sünek davranış tasarım ilkelerine ve Deprem Bölgelerinde yapılacak Binalar Hakkında Yönetmelik2007 'de [17] verilen tasarım kurallarına uygun olacak şekilde, çelik profil gömülü kompozit kolon elemanların tasarımı Çelik Yapıların Tasarımı, 2016 taslak şartnamesinde [18] ve EUROCODE 4'de [19] verilen tasarım kurallarına uygun olarak yapılmıştır.

\subsection{Kompozit kolon tasarımı}

EUROCODE 4 ve Çelik Yapıların Tasarımı ve Yapım Kuralları taslak yönetmeliğine (2016) göre yapılmış çelik profil gömülü kompozit kolonun tasarımı Şekil 2'de verilmiştir

Çelik Yapıların Tasarım ve Yapım Kuralları taslak yönetmeliğine göre betona gömülü kompozit elemanlar için minimum kurallar:

(a) Yapısal çelik çekirdeğin enkesit alanı, toplam kompozit enkesit alanının en az \%1 i kadar olmalıdır. 
B.Arısoy ve F. Şermet / Kompozit Kolon-Betonarme Kiriș Birleşim Noktasının Tersinir Tekrarlı Yükler Altındaki Davranıșının Numerik Olarak İncelenmesi.

(b) Kompozit kesitte boyuna ve enine donatı kullanılmalıdır. Enine donatı etriye veya spiral fret șeklinde olabilir. Etriye kullanılması durumunda $10 \mathrm{~mm}$ çapında etriyeler en fazla $300 \mathrm{~mm}$ aralıkla, $12 \mathrm{~mm}$ veya daha büyük çapl etriyeler en fazla $400 \mathrm{~mm}$ aralıkla teșkil edilmelidir. Etriye aralı̆̆ kompozit elemanın en küçük kenar uzunluğunun 0.5 katından daha fazla olamaz.

(c) $\rho_{\mathrm{sr}}=\mathrm{A}_{\mathrm{sr}} / \mathrm{A}_{\mathrm{g}}$ ile tanimlanan boyuna donatı oranı, $\rho_{\text {sr }}$ nin minimum değeri 0,004 olacaktır. Burada $\mathrm{Ag}$, kompozit elemanın toplam enkesit alanı, $A_{s r}$, boyuna donatı alanıdır.

Nümerik analizlerde kullanılacak elemanların tasarımı yukarıda verilen kurallara uygun olarak tasarlanmıştır.

\section{Birleşim bölgesi tasarımı}

Bu çalışmada çelik profil çekirdekli beton kompozit kolon-betonarme kiriș düğüm noktasının tersinir tekrarlı yük etkisi altındaki davranışı, göçme şekilleri, yük aktarma/dayanım performansı numerik olarak analiz edilmek ve depreme dayanıklı yapı tasarımı kurallarına uygun tasarlanmış betonarme kolon-kiriş düğüm noktasının aynı yükler etkisi altındaki davranışı ile kıyaslamak üzere geometrik ölçüleri aynı olan elemanlar tasarlanmıştır. Analiz edilecek düğüm noktası, 200x200mm ölçülerinde kolon ve kiriş elemanların düzlemde birleştiği, çerçeve sistemin iç düğüm noktası olarak tasarlanmıştır. Kirişlerde moment sıfır noktası düğüm noktasından $1200 \mathrm{~mm}$, kolonlarda moment sıfır noktası düğüm noktasindan $\quad 800 \mathrm{~mm}$ uzakta tasarlanmıștır. Kompozit kolon içine IPE100 çelik profil gömülmüş, ayrıca $4 \phi 12$ boyuna donatı ve $\phi 10 / 10$ kesme donatısı eklenmiştir. Kiriş, çekme bölgesinde $3 \phi 12$, basınç bölgesinde $2 \phi 12$ boyuna donatı ve $\phi 10 / 6$ kesme donatısı ile tasarlanmıştır. Kompozit kolonbetonarme kiriş düğüm noktasının tersinir tekrarlı yükler etkisindeki davranışını kıyaslamak üzere analiz edilecek betonarme kolon-kiriș düğüm noktasında kolon içine çekme ve basınç bölgelerine $3 \phi 12$ boyuna, $\phi 10 / 6$ kesme donatısı, kiriş içine kompozit kolonbetonarme kiriş birleşiminde kiriş içinde kullanılan donatı miktarında donatı kullanılmıștır. Analiz edilecek birleșim bölgesi detayları Şekil 2'de ve malzeme özellikleri Tablo 1' gösterilmiştir.

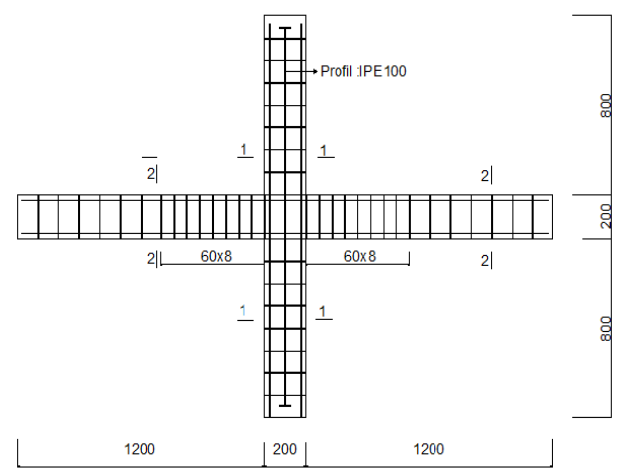

(a)

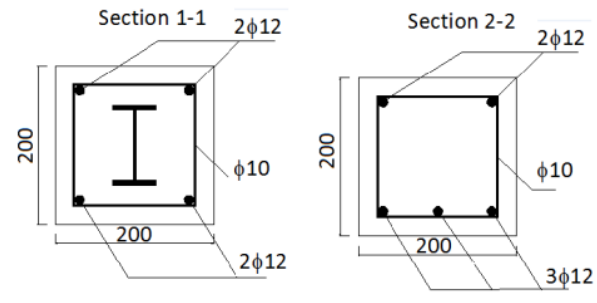

(b)

Şekil 2. a) Kompozit kolon-betonarme kiriș birleșim, b) Eleman kesit detayları

Düğüm noktası birleşim elemanı kiriş moment sifir ve kolon alt noktasindan basit mesnetlenmiș ve kolon üst moment sıfır noktasından tersinir tekrarlı yük ile yüklenerek analiz edilmiştir. Düğüm noktaları ABAQUS programı içinde modellenmiş ve lineer olmayan analiz yöntemi ile analiz edilmiştir. 
B.Arısoy ve F. Şermet / Kompozit Kolon-Betonarme Kiriș Birleşim Noktasının Tersinir Tekrarlı Yükler Altındaki Davranıșının Numerik Olarak İncelenmesi.

Tablo 1. Malzeme özellikleri

\begin{tabular}{lccccc}
\hline & $\begin{array}{c}\text { Basınç } \\
\text { Dayanımı } \\
(\mathrm{MPa})\end{array}$ & $\begin{array}{c}\text { Akma } \\
\text { Dayanımı } \\
(\mathrm{MPa})\end{array}$ & $\begin{array}{c}\text { Yoğunluk } \\
\left(\mathrm{kg} / \mathrm{m}^{3}\right)\end{array}$ & $\begin{array}{c}\text { Elastisite } \\
\text { Modülü } \\
(\mathrm{MPa})\end{array}$ & $\begin{array}{c}\text { Poisson } \\
\text { Oranı }\end{array}$ \\
\hline Beton & 30 & & 2400 & 32 & 0.2 \\
Çelik Profil & 420 & 420 & 7850 & 200 & 0.3 \\
Donatı Çubuğu & 420 & 420 & 7850 & 200 & 0.3 \\
\hline
\end{tabular}

\section{Sonlu elemanlar modeli}

Kompozit kolonun sonlu eleman modelinin hazırlanmasında çelik profilin beton tarafında tam olarak sarılmasına özellikle dikkat edilmiștir. Kolon-kiriş birleșim bölgesi modellemesi ABAQUS kullanıcı kllavuzuna [20] uygun olarak beton ve IPE100 çelik profil için üç boyutlu katı eleman (B31), çelik profil için çubuk eleman (T3D2) kullanılarak yapılmıştır. Her iki tip düğüm noktası birleşimi beton sonlu elemanlar modeli Şekil 3, kompozit kolon-betonarme kiriș düğüm noktası donatı sonlu elemanlar modeli Şekil 4, ve betonarme kolon-kiriş birleşimi donatı sonlu elemanlar modeli Şekil 5'de verilmiștir.

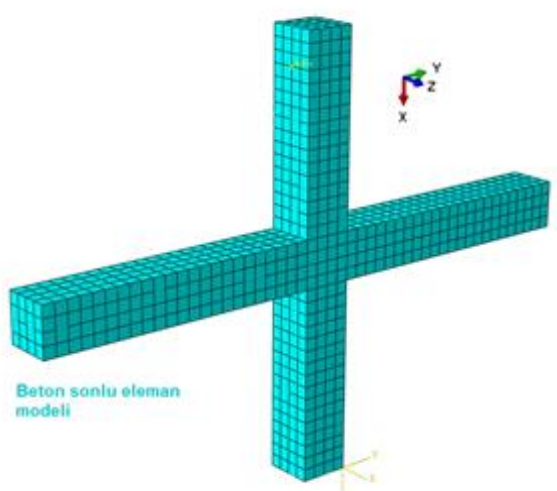

Şekil 3. Düğüm noktası beton sonlu elemanlar modeli

Kompozit kolon-betonarme kiriş birleșim eleman modeli kolon alt ucu ve kiriş uçlarından düşey yer değiştirmeler engellenecek şekilde sabit mesnetli olarak bağlanmıştır ve kolon üst ucundan yatay olarak yüklenmiştir.

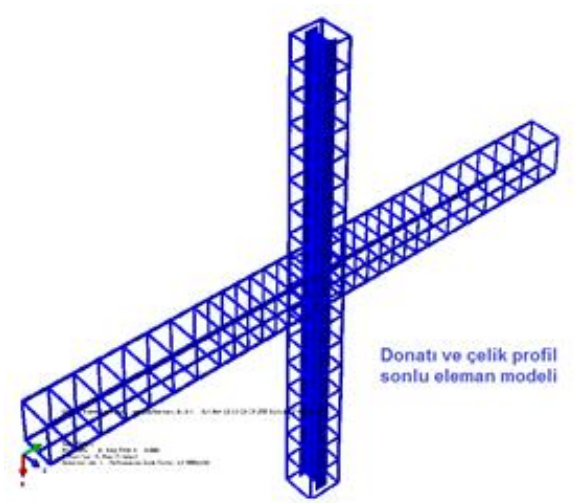

Şekil 4. Kompozit kolon-betonarme kiriş düğüm noktası donatı sonlu elemanlar modeli

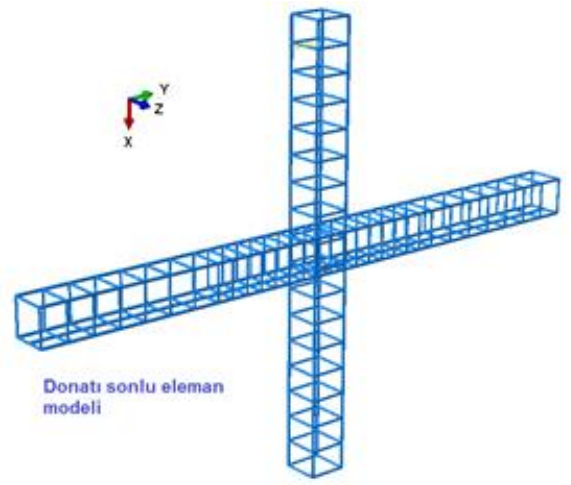

Şekil 5. Betonarme kolon-kiriş düğüm noktası donatı sonlu elemanlar modeli

Birleşim elemanı mesnet koşulları ve yükleme şekli Şekil 6'da verilmiştir. Modelde kompozit kolon içinde yer alan çelik profil ile beton arasında bağlantıyı tanımlayan kontak elemanlar tanımlanmıștır. 
B.Arısoy ve F. Şermet / Kompozit Kolon-Betonarme Kiriș Birleşim Noktasının Tersinir Tekrarlı Yükler Altındaki Davranıșının Numerik Olarak İncelenmesi.

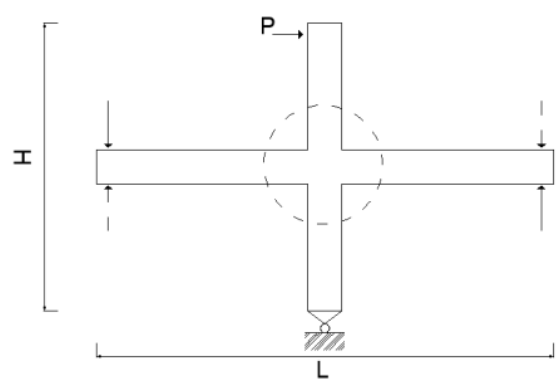

Şekil 6. Birleşim elemanı sınır koşulları ve yükleme şekli

Kompozit kolonun elasto-plastik davranıșı betonarme kolon-kiriș elastoplastik davranışı olarak simule edilmiştir. Betonarme ve beton-çelik kompozit elemanların yük etkisi altında plastik mafsallaşmaların oluştuğu bölgelerde gerilme dağılımları ve plastik deformasyonların önemi büyüktür ve dolayısı ile modellerdeki eleman sayısı yeterli miktarlarda olmalıdır. Modellerde eleman sayısı kritik bölgelerde arttırılmalıdır. Çalışmada, betonarme kolon- kiriș modelinde beton için 1632 (C3D8R) eleman, donatı için 5852 (T3D2) eleman kullanılmıştır. Kompozit kolon-betonarme kiriş modelinde beton 1632 (C3D8R) eleman, donatı için 6799 eleman kullanılmıştır. IPE100 yapısal çelik profili için 20 (B31) eleman kullanılmıştır.

Her iki tip birleşim bölgesi, kompozit kolon-betonarme kiriş ve betonarme kolon-kiriş birleşim bölgesi, tersinir tekrarlı yük etkisi altında analiz edilmiştir (Şekil 7).

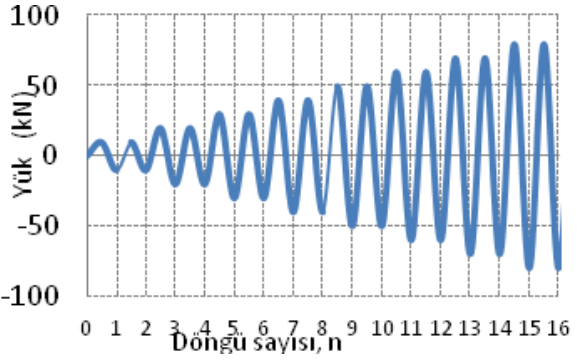

Şekil 7. Tekrarlı tersinir yük döngüsü

\section{Numerik Analiz Sonuçları}

Her iki tip birleşim elemanının kompozit kolon-betonarme kiriș ve betonarme kolon-betonarme kiriștersinir tekrarlı yük etkisi altındaki davranışı lineer olmayan analiz yöntemi ile ABAQUS programı ile analiz edilmiștir. Betonarme kolon-betonarme kiriş birleşim elemanında basınç ve çekme gerime artışları 9. çevrimde başlamış, 10 . çevrimden sonra da betonda en büyük basınç, donatılarda akma gerilmelerine 47,97 KN'da ulaşılmıştır. Betonarme kolonbetonarme kiriş birleşim elemanının düğüm noktası yük-yer değiștirme diyagramı Şekil 8'de, birleşim elemanı gerilme dağllımları Șekil 9'da verilmiștir. Yük-yer değiștirme grafiği, Şekil 7'de verilen yük döngüsünün birleşim elemanının birleşim bölgesinde seçilmiș bir elemanın deplasmanı ile ilişkilendirilmesidir. Deplasmanı ölçülen eleman kolon-kiriş eksenlerinin birleştiği noktadan seçilmiştir, böylece çerçeve sistemin düğüm noktası deplasmanları, çerçeve yatay yük etkisi altındayken ne mertebelerde olduğu tespit edilmiştir. Şekil 8' de görüldüğü üzere birleşim elemanı göçme gerilmelerine ulaşmış olduğu 47,97 KN yüke karşılık düğüm noktası $185 \mathrm{~mm}$ yer değiştirme yapmıştır

Şekil 9'da verilen eleman gerilme dağılımları betondaki en büyük basınç nümerik analiz sırasında yükleme ve gerilme ilişkisinin takip edilebilmesi, malzemelerin hangisinin önce göçtüğünün tespit edilme olanağını sağlamıştır. Betonarme kolonbetonarme kiriş birleşim ele elemanı yük döngüsü tamamlandığında kiriş içindeki donatılar akmış (Şekil 10), yük diğer yönden etkimeye başladığında kolon donatıları en büyük akma gerilmelerine ulaşmış, analize devam edildiğinde 10. yük döngüsünde beton en büyük gerilmesi 30MPa'la ulașmıștır. 
B.Arısoy ve F. Şermet / Kompozit Kolon-Betonarme Kiriș Birleşim Noktasının Tersinir Tekrarlı Yükler Altındaki Davranışının Numerik Olarak İncelenmesi.

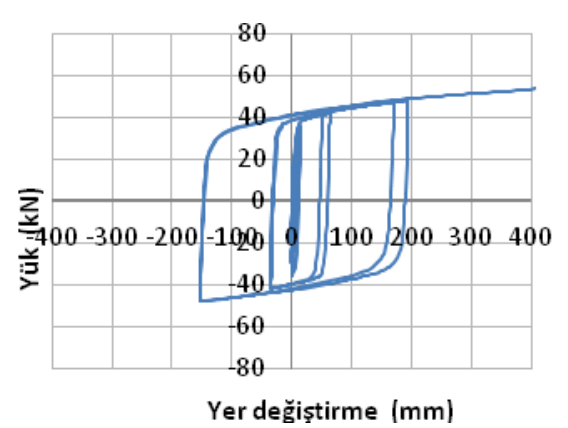

Sekil 8. Betonarme kolon-betonarme kiriş birleşim tepe noktası yük-düğüm noktası yer değiştirmesi

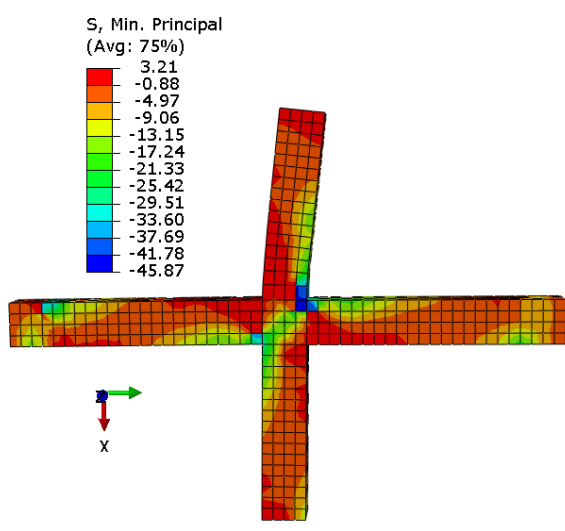

Şekil 9. Betonarme kolon-betonarme kiriş birleșim elemanı beton gerilme dağılımları

Artan yükler etkisi altında tam göçme $45 \mathrm{MPa}$ basınçta gerçekleşmiştir. Beton basınç gerilme dağılımları incelendiğinde, basınç gerilmelerinin kolon ve kirişin birleștiği bölgede hem kiriș hem de kolon üzerinde oluştuğu görülmüştür.

Kompozit kolon-betonarme kiriş birleşim elemanının düğüm noktası yükyer değiştirme diyagramı Şekil 11'de, birleşim elemanı gerilme dağılımları Şekil 12'de verilmiştir.

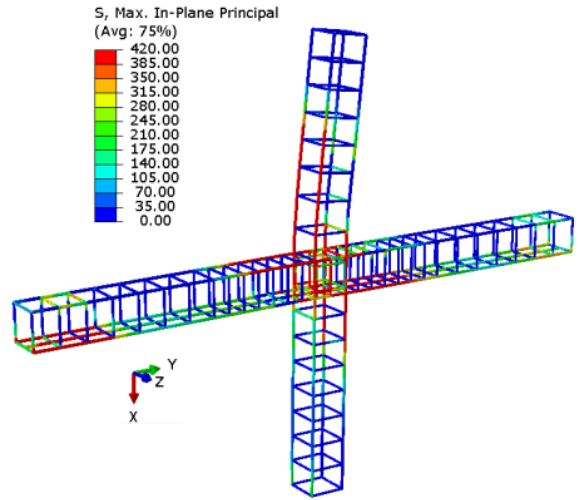

Şekil 10. Betonarme kolon-betonarme kiriş birleşim elemanı donatı gerilme dağılımları

Şekil 11'de görüldüğü üzere birleşim elemanı göçme gerilmelerine ulaşmış olduğu 63,62 KN yüke karşılık düğüm noktası 303mm yer değiştirme yapmıştır.

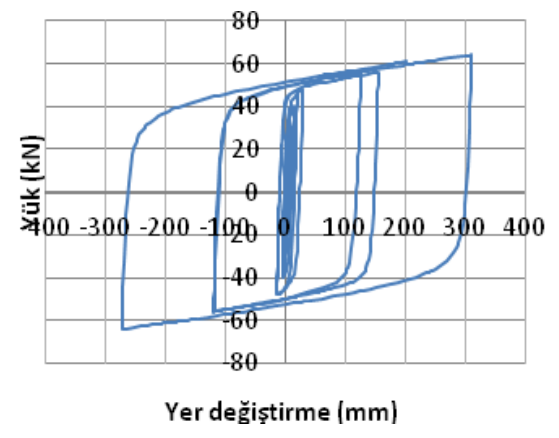

Şekil 11. Kompozit kolon-betonarme kiriş birleşim tepe noktası yük-düğüm noktası yer değiştirmesi

Şekil 12'de verilen kompozit kolonbetonarme kiriş birleşim elemanı beton gerilme dağılımları incelendiğinde basınç gerilmelerinin kolon ve kiriş birleşim bölgesinde sadece kiriş üzerinde oluştuğu görülmüştür. Kompozit kolon içinde yer alan çelik profil kolon elemanın sünek olmasını sağlamıș, bu bölgedeki beton ezilmesine rağmen basınç yükünü çelik profil taşımaya devam etmiş, dolayısı ile göçme kiriş kısmında gerçekleşmiştir. 
B.Arısoy ve F. Şermet / Kompozit Kolon-Betonarme Kiriș Birleşim Noktasının Tersinir Tekrarlı Yükler Altındaki Davranıșının Numerik Olarak İncelenmesi.

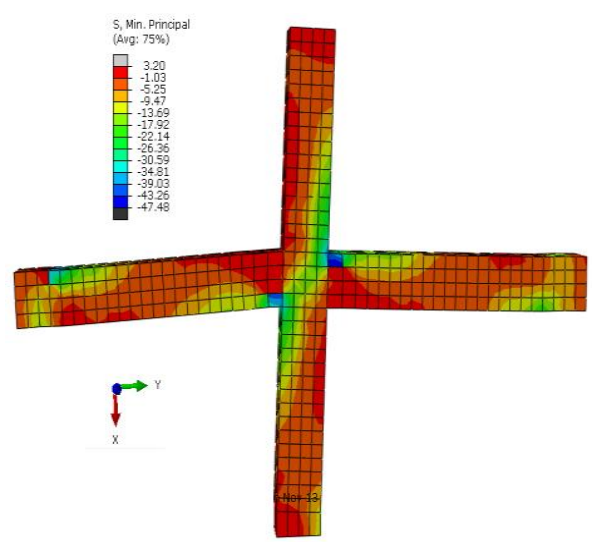

Şekil 12. Kompozit kolon-betonarme kiriş birleşim elemanı beton gerilme dağılımları

Kompozit kolon-betonarme kiriș birleşim elemanı donatı çekme gerilmeleri diyagramı Şekil 13'de verilmiştir.

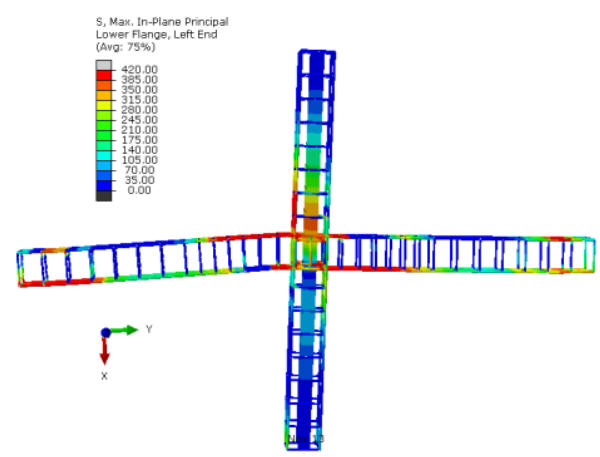

Şekil 13. Kompozit kolon-betonarme kiriş birleşim elemanı donatı gerilme dağllımları

Kompozit kolon içinde yer alan yapısal çelik profilin etkisiyle gerilmeler daha dengeli bir yayılma göstermiştir. Çelik profil, yumuşak donatının akmasından sonra çekme gerilmelerinin alarak taşıma kapasitesini ve sünekliği arttırmıştır. Tekrarlı yüklemeler boyunca çelik elemanlarda burkulma gözlenmemiștir. Bununla beraber takip edilen yükleme analizlerinde, kiriș donatıları, kolon donatılarından önce akmiștır.

Moment-eğrilik ilişkisi kesit davranışının en iyi şekilde anlaşılması için kullanılan parametredir. Kesit özelliklerinin farklı olması açısından kolonun kirișe saplandığı bölgedeki moment-eğrilik grafiği Şekil 14'de verilmiştir. Grafikten anlaşılacağı üzere komposit kolon-betonarme kiris birleșim elemanının eğrilik sünekliği betonarme kolon-kiriș birleșim elemanından yüksek olmakla beraber, daha rijit bir davranış sergilediği görülmüştür.

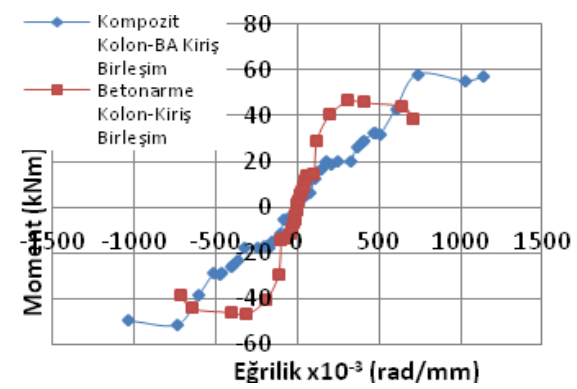

Sekil 14. Birleșim elemanları momenteğrilik ilişkisi

\section{Rijitlik}

Birleşim elemanlarının artan yer değiştirmeler sonucunda rijitlik derecelerinde değişim gözlemlenmiştir. Döngüsel rijitlik katsayıları, yükdeplasman ilişkisini kullanarak $\mathrm{K}_{\mathrm{j}}=\mathrm{P}_{\mathrm{j}} / \Delta_{\mathrm{j}}$ kolaylıkla elde edilebilir. Burada $\mathrm{P}_{\mathrm{j}}$, yük, $\Delta_{\mathrm{j}}$ yer değiştirmelerdir. Betonarme kiriş-kolon ve çelik profil gömülü kompozit kolon-betonarme kiris birleșim elemanı yük etkisi altında rijitlik katsayı, $\mathrm{K}_{\mathbf{j}}$, bağıl yer değiştirmeye $\left(\Delta_{\mathrm{j}} / \Delta_{\mathrm{y}}\right)$ bağlı grafiği Şekil 14'de verilmiştir. Burada $\Delta_{\mathrm{y}}$ akma anındaki yer değiștirmedir. Șekil 15 'de verilen grafik incelendiğinde her iki birleșim elemanı da betonun çatlaması donatı çeliğinin ve çelik profilin akması sonucu belirgin bir şekilde rijitlik kaybı 
meydana gelmiş olduğu görülmektedir. Bununla beraber kompozit kolonbetonarme birleșim elemanının daha rijit davrandığı belirlenmiștir

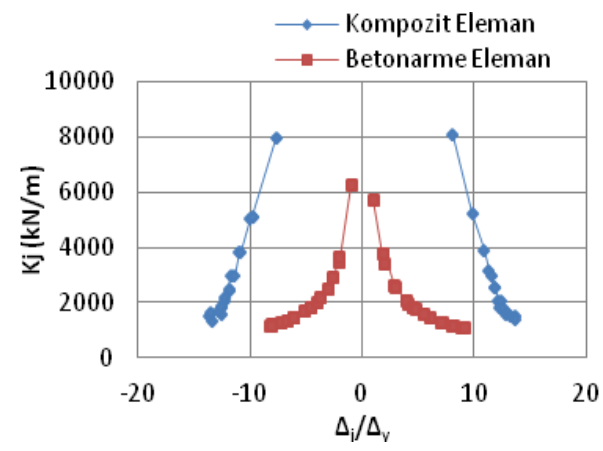

Şekil 15. Rijitlik değişimlerinin bağıl yer değiştirmeye bağlı grafiği

Tablo 2. Yük ve deplasman değerleri

\begin{tabular}{|c|c|c|c|c|c|c|c|c|c|c|c|c|}
\hline \multirow{3}{*}{ Eleman } & \multicolumn{4}{|c|}{ Akma } & \multicolumn{4}{|c|}{ Maksimum Yük } & \multicolumn{4}{|c|}{ Kopma } \\
\hline & \multicolumn{2}{|c|}{ Py $(\mathrm{kN})$} & \multicolumn{2}{|c|}{$\Delta y(\mathrm{~mm})$} & \multicolumn{2}{|c|}{$\operatorname{Pmax}(\mathrm{kN})$} & \multicolumn{2}{|c|}{$\Delta \max (\mathrm{mm})$} & \multicolumn{2}{|c|}{$\mathrm{Pu}(\mathrm{kN})$} & \multicolumn{2}{|c|}{$\Delta \mathrm{u}(\mathrm{mm})$} \\
\hline & $(+)$ & $(-)$ & $(+)$ & $(-)$ & $(+)$ & $(-)$ & $(+)$ & & $(+)$ & & $(+)$ & $(-)$ \\
\hline Betonarme & 34,9 & 19,18 & 9,69 & 41,94 & 47,99 & 47,96 & 170,35 & 153,12 & 40,79 & 40,77 & 175,38 & 162,35 \\
\hline Kompozit & 47,94 & 47,65 & 29,99 & 13,28 & 63,99 & 63,99 & 311,01 & 271 & 54,39 & 54,39 & 316,24 & 278,2 \\
\hline
\end{tabular}

Tablo 3. Süneklik oranları ve enerji yutma kapasitesi

\begin{tabular}{lcccc} 
Eleman & $\mu(+)$ & $\mu(-)$ & $\mu_{\text {ort }}$ & $E_{\text {toplam}}(J)$ \\
\hline Betonarme & 18,09 & 3,87 & 10,98 & 1263,51 \\
Kompozit & 10,54 & 18,09 & 14,32 & 2867,06 \\
\hline
\end{tabular}

\section{Süneklik}

Yük-yer değiştirme eğrilerinden yararlanılarak yapılan süneklik değerlendirmesinde betonarme kolon kiriş birleşimi 34,90kN' da akmaya başlamış olup 9,69mm deplasman yapmıştır. Çevrimsel yükün artmasıyla birlikte birleşim bölgesinin taşıdığı yük ve deplasman artmaktadır. Maksimum taşıma kapasitesine 47,99kN' da ulaşmış olup 170,35mm deplasman yapmıştır (Şekil 8).
Kompozit kolon- betonarme kiriş birleşimi 47,94kN' da akmaya başlamış olup 29,99mm deplasman yapmaktadır. Eleman maksimum taşıma kapasitesine $63,99 \mathrm{kN}^{\prime}$ da ulaşmış olup 311,01mm deplasman yapmıştır (Şekil 11). Süneklik oranları açısından değerlendirme yapılmak istenirse; süneklik oranı, $\mu=\Delta_{\mathrm{y}} / \Delta_{\mathrm{u}}$, akma anındaki deplasmanın, $\Delta_{y}$, maksimum yükün \%85'ine karşılık gelen deplasmana, $\Delta_{\mathrm{u}}$, oranı olarak hesaplanabilir [21]. Birleşim elemanlarına ait akma yükü, maksimum yük, kopma yükü ve bu yüklere karşılık gelen yer değiştirmeler Tablo 2'de verilmiştir. $\mathrm{Bu}$ değerler kullanılarak hesaplanan süneklik oranları Tablo 3'de verilmiştir.
Tablo 3'de görüldüğü üzere kopma anında kompozit birleşim elemanı betonarme birleșim elemanına göre daha fazla deplasman yaparak daha sünek davranış sergilemiștir.

\section{Enerji yutma kapasitesi}

Enerji yutma kapasitesi genel olarak yük-deplasman eğrisi altında kalan alan hesaplanarak kıyaslama yapılabilir. Buna göre kompozit birleşim elemanı enerji yutma kapasitesi 2868,06 Joule iken betonarme birleşim elemanın 1263,51 Joule olarak elde edilmiştir. Dolayısıyla kompozit birleşim elemanın enerji yutma kapasitesinin daha yüksek olduğu sonucuna varılmıştır.

\section{Sonuç ve değerlendirme}

$\mathrm{Bu}$ çalışmada, kompozit kolon ve betonarme kiriş birleşim bölgesinin tersinir tekrarlı yükler etkisi altındaki 
davranışı nümerik olarak incelenmiştir. Çalışma kapsamında dügüm noktasının süneklik mertebesi ve göçme șekli incelenmiș, betonarme kolon-kiriș birleşim bölgesi performansı ile karşılaştırılmıştır. Analizler sonucunda beton ve çelik elemanlarında en büyük basınç ve çekme gerilmeleri kolon-kiriș kesişim bölgesinde meydana gelmiştir. Betonarme kolon-kiriş birleşim elemanı 47,97 kN'a kadar yatay yük taşırken 19,4 cm yer değiștirme yapmıştır. Kompozit kolon-betonarme birleşim elemanı ise $63,62 \mathrm{kN}$ yatay yük taşırken 30,3 cm yer değiştirme yapmıştır. Analiz sonuçları her iki birleşim şeklinde de kolon ve kiriş birleşim yüzeylerindeki betonun ezilmesine rağmen, kompozit kolon-betonarme kiriş birleşimi betonarme kolon-kiriş birleşimine göre göçmeden önce 1,32 kat daha fazla yatay yük taşımış, 1,56 kat daha fazla yer değiştirme yapmıştır. Betonarme kolon-kiriş birleşim bölgesinde dayanım betonun ezilmesi ile kontrol edilirken, kompozit kolonbetonarme kiriș düğüm noktasında çelik profilin akması ile kontrol edilmiştir.

\section{Teşekkür}

$\mathrm{Bu}$ çalışmada ABAQUS analizlerinin tamamlanmasinda emeği geçen Dr. Emin HÖKELEKLİ'ye teşekkürü bir borç biliriz.

\section{Kaynakça}

[1] Lee, S. J. (1987). Seismic behavior of steel building structures with composite slabs," thesis presented to Lehigh University at Bethlehem, $\mathrm{Pa}$, in partial fulfillment of the requirements for the degree of Doctor of Philosophy.

[2] Lee S-J, Lu L-W. Cyclic tests of full-scale composite joint subassemblages. JStruct Eng, ASCE 1989(8):1977-98.

[3] Lee S-J, Lu L-W. Cyclic load analysis of composite connection subassemblages. In: Bjorhovde, Colson, Hajjar, Stark, editors. Connections in steel.

[4] Chou CC, Uang CM., " Cyclic performance of a type of steel beam to steel-encased reinforced concrete column moment connection" Journal of Constructional Steel Research 2002; 58 : 637-663.

[5] Tao MX, Fan JS, Nie JG. "Seismic behavior of steel reinforced concrete columnsteel truss beam hybrid joints" (2013).

[6] Liao FY, Han LH, Tao Z. “ Behaviour of composite joints with concrete encased CFST columns under cyclic loading: Experiments" Engineering Structures 2014; 59: 745-764.

[7] Zeng L, Cui Z, Xiao Y, Jin S, and Wu Y., " Cyclical Behavior of Concrete-Encased Composite Frame Joints with High Strength Concrete" Hindawi Publishing Corporation 2015; Article ID 873162.

[8] Campian C, Nagy Z, Pop M., “ Behavior of Fully Encased SteelConcrete Composite Columns Subjected to Monotonic and Cyclic Loading" Procedia Engineering $2015 ; 117: 439$ 451.

[9] Chen CC, Chen Chien C, Hoang TT., "Role of concrete confinement of wide-flange structural steel shape in steel reinforced concrete columns under cyclic loading" Engineering Structures 2016; 110 : 79-87.

[10] Weng, C.C., Yen, S.I. Comparisons of concreteencased composite column strength provisions of ACI code and AISC specification, Engineering Structures, 2002; 24: 59-72. 
B.Arısoy ve F. Şermet / Kompozit Kolon-Betonarme Kiriș Birleşim Noktasının Tersinir Tekrarlı Yükler Altındaki Davranıșının Numerik Olarak İncelenmesi.

[11] Di Sarno, L., Pecce, M.R., Fabbrocino, G. Inelastic response of composite steel and concrete base column connections. Journal of Constructional Steel Research, 2007; 6:3 819-832

[12] Ellobody, E., Young, B. Numerical simulation of concrete encased steel composite columns. 2011Journal of Constructional Steel Research; 67:211-222

[13] Begum M, Driver, R.G. Elwi, A.E. Behaviour of partially encased composite columns with high strength Concrete. Engineering Structures, 2013, 56: 1718-1727.

[14] Gonçalves, R., Carvalho, J. An efficient geometrically exact beam element for composite columns and its application to concrete encased steel Isections. Engineering Structures, 2014; 75:213-224

[15] Yu-Feng An, Lin-Hai Han, Roeder, C. Performance of concrete-encased CFST box stub columns under axial compression, Structures 3 (2015) 211-226.

[16] Park, R., and Paulay, T., Reinforced Concrete Structures, John Wiley and Sons, 1975, 786p.

[17] Deprem Bölgelerinde Yapılacak Binalar Hakkında Yönetmelik, 2007.

[18] Çelik Yapıların Tasarım, Hesap ve Yapım Esaslarına Dair Yönetmelik, 2017

[19] Eurocode 4: Design of composite steel and concrete structures Part-1: general rules and rules for buildings. Brussels :European committee for Standardization; 2005

[20] ABAQUS standard user's manual. Vol. 1, 2 and 3 Version 6.8-1, USA: Hibbitt, Karlsson and Sorensen. Inc.; 2008.

[21] Specification for test methods of seismic buildings. Beijing: rchitecture Industrial Press of China; 1997 [in Inglish]. 